\title{
THE UNIFORM LAW ON THE INTERNATIONAL SALE OF GOODS: A CONFLICT OF LAWS IMBROGLIO*
}

\author{
KURT H. NADELMANNं
}

WITH little advance notice, American importers and exporters today face the discomforting possibility of being subject to a uniform law of world-wide application to the international sale of goods, rushed through at a diplomatic conference held at The Hague in April, 1964. Under the covering convention the uniform law will become the general law of any state which ratifies the convention, and according to the uniform law's provisions, the courts of ratifying states must disregard all other applicable principles of conflicts of laws and apply the uniform law to all cases involving international sales. This regulation of the conflicts problem, further, is contained in a law which, far from having the unanimous approval of the delegations, met with the express disapproval of the United States delegation.

The sequence of events leading to this rather extraordinary development ${ }^{1}$ shows paradoxically that the present crisis has arisen from highly commendable endeavors to bring greater security to international trade by unifying the law

*With an appendix of the Hague Convention of 1955 on the Law Applieable to International Sales of Goods.

†Research Scholar, Harvard Law School; Adjunct Professor of Law, New York University.

1. The President of the Tenth Session of the Hague Conference on Private International Law recently attacked the convention in his opening address to that session:

$[T]$ he recent conclusion of the two conventions relating to a uniform law on the international sale of goods and a uniform law on the formation of sales contracts furnishes a good example of the surprising diffculties that can arise in this domain [of unification of law]. These two conventions - said to be of July 1, 19E4 - which, furthermore, carry as place of origin "The Hague" - prescribe especially the application of the uniform law to all international cases and thus forbid the applieation of the rules of conflict of laws. Not considering certain reservations which have been allowed, these conventions create a serious collision with the existing national conflicts systems and notably the convention on the Law Applicable to International Sales of Goods. The latter convention was prepared by the Hague Conference in 1951. Signed in 1955, it entered into effect in seven states recently. I regret this situation and I find it difficult to understand why this Spring in this very city so little awareness should have been shown of the principles of private international law.

Address by President Offerhaus, Oct. 6, 1964, to appear in 1 Confrérence de L $\mathrm{H}$ Haye dE Drotr Internationar. Privé, Actes de La Dixièare Session (1964) (author's transl.).

Cf. De Winter, Loi Usiforme sur la Vente Internationale des Objets Mrobiliers Corporels et le Droit International Privé, 11 NederLands TrJdscarift voor Irterniatio:iant RECHT 271 (1964). 
on the international sale of goods. Only the law of negotiable instruments has been given higher priority than the law of sales in regional and international endeavors to attain uniformity. For negotiable instruments a high degree of uniformity has been achieved within, if not between, the common law area and that of the civil law. On sales law progress has been slower. Success has been limited to individual countries, like the United States with its Uniform Sales Act ${ }^{2}$ - now superseded by the Sales Article of the Uniform Commercial Code $^{3}$ - and closely knit regions like Scandinavia, which has had a uniform sales law since 1905.4

Unification of the law of sales can be approached in various ways. Unification can be attempted for all sales, or for international sales only. In the first case, a regional approach is possible and probably the best solution; in the second, a regional approach will fail if the concern is international, and not merely inter-regional, trade since it is unlikely that one region can impose its own "international" sales law on all other regions. For international sales a uniform substantive law is perhaps the ideal solution. If the ideal is beyond reach, the next best solution is an agreement on conflicts rules stipulating to what extent the national law of the buyer or that of the seller shall govern the contract, if the parties have not made their own choice of the governing law. An agreement on conflicts is necessary even with a uniform substantive law since no uniform substantive law is likely to cover all questions, and acceptance of a uniform law by all trade nations in the near future cannot be expected. In the case of bills of exchange and checks, the Geneva conferees of the early nineteen-thirties saw reason to create both a uniform substantive law and a set of conflicts rules. ${ }^{5}$ But the fact that nations may be able to agree on a set of conflicts rules more easily than on a uniform substantive law suggests the wisdom of approaching conflicts first. Despite such counsels of wisdom, international sales is now the subject of a contest between promoters of a uniform substantive law and champions of a conflicts agreement. The outcome of the contest remains in doubt.

The conflicts partisans were given an early advantage because the Inter* national Law Association appointed a committee on sales during its 1924

2. At one time the Uniform Act was in force in 36 states and the District of Columbia. See 1 UNIForm Laws ANN. xv (1950).

3. As of now the UNIFORM COMMMERCIAL CODE has been enacted in 29 states and the District of Columbia. See Uniforar Laws Annotated: Uniforar Comarercina Code 5 (Supp. 1963).

4. An English translation of the "Scandinavian" Sale of Goods Act may bo found in International Institute for the Unification of Private Law, 1961 Year-Book UNIFICATION OF LAW 203 (1962).

5. See Hudson \& Feller, The International Unification of Laws Concerning Bills of Exchange, 44 HARv. L. REv. 333 (1931); Feller, The Intcrnational Unification of Lazes Concerning Checks, 45 HARv. L. Rev. 668 (1932). The conflicts rules may be relied upon also in the case of different construction of the uniform law in different countries. See Lagarde, Les Interpretations Divergentes d'une Loi Uniforme Donncnt-elles Licu a un Confit de Lois?, 53 Revue Critique de Droit International Pruve 235 (1964). 
conference in Stockholm. ${ }^{8}$ The Committee prepared a draft ${ }^{7}$ of uniform conflicts rules for the 1926 Vienna Conference, and that Conference recommended that the draft be submitted to a diplomatic conference ${ }^{8}$ whose task was to be the elaboration of a convention on the basis of the draft. Following this recommendation, The Netherlands, sponsor of the Hague Conferences on Private International Law, placed the topic of conflicts of law in international sales on the agenda of the sixth session of the Hague Conference, held in January, 1928. ${ }^{9}$ After considering various drafts ${ }^{10}$ the Hague Conference requested the Government of The Netherlands to appoint a committee of experts for the preparation of a further draft to be considered at the seventh session.11 This committee, of which Professor Julliot de la Morandière of France was chairman, met at The Hague in 1931 and produced such a document. ${ }^{12}$ Hitler and the war delayed consideration of the draft and the seventh session of the Hague Conference on Private International Law until October, 1951. The Committee of Experts' draft of 1931 was taken up ${ }^{13}$ and provided the basic features of a draft of a Convention on the Law Applicable to International Sales of Goods approved in $1951 . .^{14}$ The convention was signed by Belgium, France, Luxembourg, and The Netherlands in 1955 and, early in 1956, by Italy.

At the eighth session of the Hague Conference, held in October, 1956, West Germany requested changes in the Conflicts Convention approved in $1951 .{ }^{15}$ The newly formed German Council on Private International Law had heard representatives of the German Chambers of Commerce express opposition to parts of the convention. Two changes were suggested by the German delegation. ${ }^{16}$ Under the convention the contracting parties are free to choose the law to govern the contract, but such choice must be expressly made. ${ }^{17}$ The

6. See International Law Ass'n, Report of the 33rd Conferesce at Stocknolss 395-97 (1925).

7. International Law Ass'n, Report of the 34th Conference at Vieinia 482 (1927).

8. Id. at 507 .

9. See Conférence de La Haye de Droit International Privé, Docusrewits ReLATIFS À LA SIXIÈMTE SESSION 469 (1928).

10. Id., ACTES DE LA SIXIÈMSE SESSION 267-395 (1938).

11. Id. at $395,396$.

12. Text in Conférence de La Haye de Drott International Prive, Docuasesits Retatifs À la Septième Session 4 (1952).

13. Id, Actes de LA Septrì̀ife Session 16-124 (1952).

14. Text, id. at 382. [Hereinafter referred to as Applicable Law Converitror.] English transl. in 1 Axr. J. Cossp. L. 275 (1952). The principal provisions are reproduced in the Appendix.

15. See Conférence de la Haye de Drort International Privé, Actes de ia Hutrième Session 37, 38 (1957).

16. Id., Docunents Relatifs à la Hutrièare Session 232-42 (1957).

17. Applicable Iaw Convention, art. 2. For a discussion in English see Wortley, The 1951 Hagne Conference on Private Infernational Law, 38 Transact. Gror. Soc'x 25 (1953) ; Offerhaus, The Seventz Session of the Hague Conference on Prizate International Laze, 79 JourNal DU DROIT INTERNatronaL 1071, 1077 (1952). 
Germans argued that according to custom a designation in a contract of a jurisdiction for litigation or arbitration implies choice of the law of that jurisdiction. ${ }^{18}$ In view of the requirement in the convention of an express clause, the courts would be unable to honor this custom. Second, in the opinion of the Germans the convention had gone too far in providing for application of the law of the buyer. Under the convention the law of the seller normally applies, but when an order is received by the seller or his representative in the buyer's country the buyer's law applies. ${ }^{10}$ The Germans asked that this exception be altered so that the buyer's law would be applicable only when the delivery of the goods is to be in his country and he can reasonably expect the goods to come from stocks held there. ${ }^{20}$

The French Delegation vehemently opposed any change in the convention as approved in 1951.21 Their argument was technical: a convention signed though not yet ratified - by a number of governments should not be reopened for discussion lest a bad precedent be set. The French were supported by most of the other delegations. The delegate of the United Kingdom expressed sympathy with the first point made by the Germans, ${ }^{22}$ and the President of the Conference, speaking on behalf of the Dutch Delegation, favored a discussion of both points on the merits; ${ }^{23}$ but only four nations - Germany, Austrit, Switzerland, and Turkey - voted in support of the proposed re-examination. ${ }^{24}$

Accommodation on the Germans' first suggestion might have been casy, but the second objection raised basic policy questions. Perhaps for this reason, the fate of the convention remained long in doubt. Five ratifications were required to put it into effect: ${ }^{25}$ Italy ratified the convention in 1958 , Belgium in 1962 , and France in $1963 ;^{26}$ since then the Scandinavian countries have ratified, and the convention became effective September 1, 1964.27

18. Qui elegit judicem elegit jus. See 2 Raber, Conflict of Laws: A Comparatrva Study 386-89 (2d ed. 1960); Cheshire, Prtyate Internatronar Law 222 (6th ed. 1961); Batiffor, Tratté Elementatre de Drotr Interanational PrufE, No. 595, at 648 (3d ed, 1959).

19. Applicable Law Convention, art. 3(2). See Wortley, supra note 17; Offerhaus, supra note 17. And see art. 4 for a limited application of the law of the place of performance.

20. Dr. Rabel had criticized the Committee draft of 1931 - that is, the system of the Convention, 3 Raber, Confuict of Laws: A Comparative Study 55, 58-60 (2d cd. 1964). This volume appeared shortly before the seventh session. The Germans now make this criticism their own.

21. See Conference de la Haye de Drott Internatronat prdve, Actis de la Huttième Session 39 (1957). Cf. Travaux du Comite Frangais de Droit InternatronAL PrIVÉ 1958-59, at 64-65 (1960).

22. CONPERENCE, op. cit. supra note 21 , at 34 .

23. Id. at 41.

24. Id. at 42-43. The American observers present at the session took no part in the discussion.

25. Applicable law Convention, art. 9.

26. See Table in 53 Revue Critrque de Droit Internatronal Prive 162, 163 (1964).

27. Sept. 1, 1964 for Belgium, Denmark, Finland, France, Italy, and Norway, Sept. 6, 1964 for Sweden. 
While these developments were taking place in unification of conflicts rules, steps were being taken toward a uniform substantive law. A committee composed of renowned experts from England, France, Germany, and Sweden, appointed by the newly formed International (Rome) Institute for the Unifcation of Private Law (Miussolini's present to the League of Nations), circulated two drafts of a uniform law on the international sale of goods during the 1930's. ${ }^{28}$ After the war, at the suggestion of The Netherlands, the reorganized Rome Institute called a diplomatic conference to consider the pre-war draft. ${ }^{29}$ Some twenty governments participated in the conference which took place in November, 1951, immediately following the seventh session of the Hague Conference which produced the Conflicts Convention. The United States had an observer who took no part in the debates. After the draft was discussed, a number of recommendations were made, and a committee composed of experts from France, West Germany, Italy, The Netherlands, Sweden, Switzerland, and the United Kingdom was appointed to revise the draft. ${ }^{\circ}$ The revised draft was completed in 1956, ${ }^{31}$ and a second diplomatic conference was called to consider it. The conference, attended by 26 governments, ${ }^{32}$ including that of the United States, met at The Hague for three weeks in April, 1964, and produced a convention relating to a Uniform Law on the International Sale of Goods, with a Uniform Law as an appendix, and a convention relating to a Uniform Law on the Formation of Contracts for the International Sale of Goods, with a Uniform Law on that topic as an appendix. ${ }^{33}$

28. A first draft was communicated by the League of Nations to the governments for their comments in 1935. INSTTYUT INTERNATTONALE DE ROSTE FOUR L'UNIFICATIO:: ne Dr.olt Privé, Soctéte des Nations, Projet d'une Lor sur la Vente Interenatroitale des Objets MobIters CoRporers (1935). On the basis of these comments, the committee prepared a revised draft consisting of 105 articles, which became available in 1939. Irrstrrur International de Roare pour I'Unification du Droit Prive, Soctété des Nations, Projet d'une Loi sur la Vente Internationale des Objets Mobiliers Corfonels et

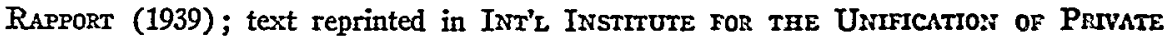
LAw, 1948 YeAreOOK UNIFICATYON of LAw 102-59. See Nadelmann, The Uniled Stales and Plans for a Uniform (World) Law on International Sales of Goods, 112 U. PA. L. REv. 697 (1964).

29. Text in 1948 UnIFICATION of LAW, op. cit. supra note 28.

30. Actes de la Conférence, Convoquée par le Gouvernearent Royal das PaysBas, sur un Projet de Convention Relatif a une Lor Uniforase sur la Verite D'ObJets MobIIJERs Corporess 269-79 (1952). See Rabel, The Hagne Conferenec on Unification of Sales Law, 1 Axr. J. Coxrp. L. 58 (1952).

31. On the revised draft see Honnold, $A$ Uniform Law for International Sales, 107 U. PA. I. Rev. 299 (1959). For the text of the draft see 7 INT'L \& Co:rr. LQ. 3 (1958).

32. Austria, Belgium, Bulgaria, Colombia, Denmark, Finland, France, West Germany, Greece, Hungary, Ireland, Israel, Italy, Japan, Luxembourg, The Netherlands, Norvay, Portugal, San Marino, Spain, Sweden, Switzerland, Turkey, United Arab Republic, United Kingdom, United States, Vatican City, Yugoslavia. The United States delegation was composed of Richard D. Kearney, Deputy Legal Adviser, Department of State; Joe C. Barrett and James C. Dezendorf, Commissioners on Uniform State Laws; Professors John Honnold and Soia Mentschikoff; John N. Washburn, Office of the Legal Adviser.

33. Texts to appear in 13 Axr. J. Cosrp. In No. 3 (1964) [hereinafter cited as SArzs Convention]. 
These two conventions, which have the official date of July 1, 1964, are open for signature until the end of $1965 .{ }^{34}, 35$ Five ratifications are required to put them into effect. ${ }^{36}$ The conventions provide a procedure for amendment. After they have been in operation for three years, any contracting state can request the convening of a conference to revise the conventions or their appendices. ${ }^{37}$ If the principal convention has not been ratified by five nations by May, 1968, under a recommendation proposed by the United States delegation and adopted at the closing session, the Rome Institute will appoint a committee to investigate what else can be done to promote the unification of the law of international sales.38

Under the Sales Convention each state undertakes to incorporate into its domestic legislation the Uniform Law on the International Sale of Goods ${ }^{\text {so }}$ The Uniform Law provides that rules of private international law otherwise applicable to international sales shall not apply to any situations which the Uniform Law purports to cover. ${ }^{40}$ The law covers any contract entered into by parties with places of business (or habitual residences) in different states if the contract requires goods to be carried from the territory of one state to the territory of another, or if the acts constituting the offer and acceptance have been effected in the territories of different states, or if delivery of the goods is to be made in the territory of a state other than that within the territory of which the acts constituting the offer and the acceptance have been effected. ${ }^{41}$

The convention allows states to ratify with certain reservations. A state can opt to apply the Uniform Law only to cases in which the parties to the contract have their places of business (or their habitual residences) in different contracting states, ${ }^{42}$ rather than simply in different states. Further, states which had previously ratified the Hague Conflicts Convention on the Law Applicable to International Sales of Goods may ratify the new convention with VI.

34. Sales Conventron, art. VIII; Convention on Formation of Contracts, art.

35. The Netherlands, Greece, San Marino, the United Kingdom, and Italy. No reservations or declarations were made.

36. Sales Convention, art. X(1); Convention on Formation of Contracts, art. VIII(1).

37. Such a conference will be called if at least one-fourth of the contracting states support the request; non-contracting states may attend the conference as observers without the right to vote. Sales Conventron, art. XIV; Convention on tine Formatron on Con* TRACTS, art. XII.

38. See Final Act of the Diplomatic Conference on the Unification on Law Governing the INT'L SALE of Goods, Recommendation No. II(2).

39. Sales Convention, art. I(1).

40. UNIFORA SALES LAW, art. 2.

41. UNIFoRM SALES Law, art. 1(1). In the case of contracts by correspondence, offer and acceptance shall be considered to have been effected in the territory of the same state only if the letters, telegrams, or other documentary communications which contain them have been sent and received in the territory of that State. Id., art. 1(4).

42. Sales Convention, art: III. 
the reservation that the Uniform Law shall apply only in cases in which the Conflicts Convention requires application of that law. ${ }^{43}$ Any state may also ratify the convention with the proviso that it shall apply only to contracts in which the parties have chosen the uniform law as the law of the contract.4s (The United Kingdom was the promoter of this reservation, which was adopted after substantial initial opposition.) Finally, two or more contracting states may declare that they agree not to consider themselves as different states within the meaning and for the purposes of the Uniform Law because they have the same or closely related sales law ${ }^{45}$ and thereby exclude the application of the Uniform Law among themselves. (At least this was the apparent intention of the Scandinavian countries, sponsors of this exception.)

Reservations permitted by a convention usually reflect the quality of the work done and the degree of agreement actually reached. The reservations in the instant case sugggest that even apart from the conflicts issue, the two drafts of substantive law were in no way ready for final action at the end of the three weeks of consideration. ${ }^{46}$ Domestic legislation usually requires many readings, ${ }^{\mathbf{4 7}}$ and there is no reason to believe that less study is required to produce an adequate text of a difficult international document of 101 articles in two languages. The proceedings of the conference, when they become available, will show the time limitations under which the conferees labored. Pressure was exerted by some delegations, especially those whose countries had been represented in the drafting committee, to bring the drafts to a vote. This would be the last chance, they intimated before the meeting, to obtain an international convention: otherwise "the Continent" or "the Common Market" would establish its own. That the United States had not participated

43. Sales Convention, art. IV.

44. Sales Convention, art. V. No ratification of the convention is required for this purpose. As provided for by Article 4 of the Uniform Law, the Uniform Lav shall also apply "where it has been chosen as the law of the contract by the parties ..., to the extent that it does not affect the application of any mandatory provisions of the law which would have been applicable if the parties had not chosen the Uniform Law."

45. Sales Convention, art II(1). The declaration may also be made unilaterally; it will have effect unless rejected by the other state at the time of ratification. $I d$, art. II (2) (3).

46. [T] here has been amendment after amendment incorporated into this law whose consequences require considerable study, whose results are perhaps unforescen, and whose consequences have been to load upon the drafting Committee a burden of which no group of men, even as brilliant as, for example, Professor Tunc, could carry.

From the statement made by the head of the United States Delegation at the Plenary Session, April 25, 1964. Cf. Tunc, Les Conventions de La Haye du Ior Juillet 19 of Portant Loi Uniforme sur la Vente Internationale d'Objets Mobiliers Corporels, 16 REvoe InTEsnationale de Droit CoMrparé 547, 551-52 (1964).

47. The history of the Uniform Commercial Code may be recilled. The Code became acceptable nationally only after the version of 1952 , enacted in one state, Pennsylvania, was replaced by the version of 1958. See Braucher, The Progress of the Uniform Commercial Code, 11 Axr. J. Cosr. L. 293 (1962); Malcolm, The Uniform Commercial Code in the United States, 12 InT'I \& Cosrp. L.Q. 226 (1963). 
in the preparation of the drafts made no difference to this group; the United States, it was argued, had expressed no interest in the venture at the conference held in 1951. Nor was the well-known fact that the American Commissioners on Uniform State Laws had only just begun a study of the drafts ${ }^{48}$ considered relevant. Unable to rally a sufficient number of delegations to support an adjournment, the United States delegation had little choice but to state for the record at the plenary session that, in its view, more time was needed to remove weaknesses from the draft and to produce a uniform law acceptable to the principal nations concerned.40

An adjournment of final action for a year or so would have given the needed time for further improvement and accommodations between legal systems, but whether or not all delegations cared for such accommodations is an open question. Some may have thought that a solid phalanx of continental nations could force American and English trade into submitting to the Uniform Law. In looking at these events the present political climate in Western Europe must be taken into account.

An evaluation of the substance of the Uniform Law on the International Sale of Goods is a matter for the sales law specialists. This paper will confine itself to the conflicts problems created by that draft which are exemplified by some of the reservations in the Sales Convention. The reservation on which the United Kingdom insisted - that the convention may be ratified with the proviso that the Uniform Law shall apply only if it is chosen by the parties to the contract ${ }^{50}-$ is unique in treaty law. The United Kingdom thus can ratify the convention, if for political reasons it so desires, without imposing the Uniform Law on its business community, which reportedly does not care for the project.51 Ironically, a ratification with such a reservation counts for purposes of effectuating the convention like any other ratification. A problem of a slightly different type is reflected by the "contracting states" and "Conflicts Convention" reservations, which are designed to meet conflict of laws ob-

48. See National Conference of Connissioners on Uniform State Laws, 1963 HANDBOoK 131 ; Nadelmann, supra note 28, at 700.

49. The United States did not consider that the Sales Law as presented to the conference met the requirements of the day-to-day activities of international commerce, and, in particular, that it was not consistent with the usages and practices of seaborne commerce. ... The Sales Law has been very much improved . . . but, unfortunately, there are several weaknesses which still remain. Among these are: (1) The draft points more to external trade between common boundary nations gcographically near to each other; (2) Insufficient attention has been given to international trade problems involving overseas shipments; (3) Reciprocal rights and obligations as between seller and buyer, viewed in the light of the practical realities of trade practice, are not well balanced; (4) The law will not be understood by individuals in the commercial field.

From the statement made at the Plenary Session, April 25, 1964.

50. Sales, Convention, art. V. The Uniform Law itself allows parties to a contract to choose the Uniform Law as governing law. See UnIForm SALES LAw, art. 4, supra note 44.

51. See Special Commission Appointed by the Hague Conference on tum Satz of Goods, Observations Presented by Vartous Governments 44 (1963). 
jections. Under Article 1, which defines the international sales to which the Uniform Law purports to apply, the law can be applied to cases brought in the courts of a contracting state regardless of whether either party to the contract has its business place (or habitual residence) in that state, or in any other contracting state, and regardless of whether the Uniform Law would be applicable under the conflict rules of the forum state. Thus, if a person in Canada sells goods to a person in the United States which goods must be shipped to the United States, in any subsequent disputes between the parties respecting the transaction either party can - notwithstanding the fact that neither the United States nor Canada has adopted the Uniform Law - take advantage of the law if its relevant provisions are more favorable to that party than the otherwise applicable law. The party merely brings suit in a "contracting" state which will automatically apply the Uniform Law. This result may be accomplished as long as the other party happens to have assets in a "contracting" state and presence of assets is a basis there for assumption of jurisdiction. 52

Such a shocking result is not the result of any oversight on the part of the draftsmen. At the Diplomatic Conference of 1951 attention was called to the then unsolved conflicts problems. One of the resolutions the conference adopted specifically called for further thought about territorial application of the draft law, with due regard to the conflicts problems discussed at the preceding month's session of the Hague Conference on Private International Law. But the drafting committee apparently ignored the admonition. In the report accompanying its revised draft of 1956, the committee noted - without advancing supporting reasons - that the Uniform Law applies in a court of a country which adopts the law even if the two parties to the contract have their domicile in countries that have not adopted the law. ${ }^{\text {st }}$ In their comments on the 1956 draft, Austria and West Germany strongly criticized this aspect of the draft. Austria duly noted the fact that presence of assets in a contracting state might become the only "connecting factor" with the Uniform Law and pointed to the incompatibility of such a result with general principles of conflict of laws and, in particular, with the conflicts rules agreed to at the Hague Conference on Private International Law. ${ }^{.5}$ Germany reported that its commercial circles had spoken out most forcefully against the application of the Uniform Law to a contract in which only one of the parties has its place of business (or habitual residence) in the territory of a contracting state. She

52. Presence of assets is a basis for in personam jurisdiction in, c.g., Germany, Austria, and Sweden. See Nadelmann, Jarisdictionally Improper Fora, in XXTu CEritunY Cosiparative and Conflicts Law - Iegar Essays in Honor of Hessec E. Yiitesea 321, 329 (Nadelmann, von Mehren, and Hazard, eds. 1961).

53. ACTES DE LA CONFÉrENCE, op. cit. supra note 30, at 276 (Resolution No. IX).

54. Spectal Comintssion Appointed by the Hague Conference on time Sale of Goods, Draft of a Uniforar Law on International Sale of Goods - NEv TENT PREPARED BY THE COMAMISSION AND REPORT [Translation of the French Text of 1959] 21 (1963).

55. Id., Observations Presented by Vartous Governarents 3 (1963). 
therefore recommended limitation of the operation of the Uniform Law to cases in which both parties have their places of business (or residences) in contracting states..$^{56}$ But the drafting committee remained undisturbed: it replied to the German objection: ${ }^{57}$

One Government wished to limit the application of the law; it wanted the law to come into operation when the parties have their places of business or their residences not "in the territory of different states" but only when they have them "in the territory of different contracting states." The Committee wishes to emphasize that the application of the law to parties established or residing in the territory of non-signatory states when the court hearing the case belongs to a signatory state has not escaped its attention (see Report, p. 21, penultimate paragraph I). It continues to think that this application is desirable, inasmuch as the Uniform Law for international commerce contains rules which to the Committee appear superior to the national laws. Besides, the parties [to the contract] are always free to remove the applicability of the Uniform Law in accordance with Article 6.58

The superiority attributed by the draftsmen to their own product is a more charming than convincing argument. The American lawyer is reminded of the excitement caused some years ago by the original version of the conflicts provision in the Uniform Commercial Code which would have made the Code applicable beyond what could be justified by accepted conflicts standards ${ }^{\text {to }}$ There, too, supporters of the provision pointed to the "superiority" of the Code saying that forcing it upon hesitant states would serve their best interests. $^{60}$ The spectre of a challenge of constitutionality ended that episode, ${ }^{01}$ and the provision was rewritten. Unfortunately no such challenge is possible internationally, although states which provide for judicial constitutional review may have a problem on their hands. ${ }^{22}$

Whatever the thoughts of the draftsmen, more puzzling still is the failure of the opposition at the conference, notwithstanding the preliminary objections made by their various governments, ${ }^{63}$ to block adoption of a law in violation

56. Id. at 15 .

57. Id., Note of the Spectal Commisston on the Observations Presunted ay VARIOUS GOVERNAIENTS 4 (1963).

58. UNIFORM SALES LAw, art. 3 (art. 6 of the draft) provides that the parties to a contract of sale shall be free to exclude the application thereto of the Uniform Law either entirely or partially. Such exclusion may be express or implied.

59. The 1952 version of $\S 1-105$ is reprinted and discussed in Burton, The Uniform Commercial Code and Conflict of Lazes, 9 Ans. J. Courp. L. 458, 461, 466 (1960).

60. On the controversy see Goodrich, Conflicts Niccties and Commercial Necessilics, 1952 Wrs. L. Rev. 199; Rheinstein, Conflict of Laws in the Uniform Commercial Code, 16 Law \& Contemr. Prob. 114 (1951).

61. See notably, Freund, Analysis of Conflicts of Law Provisions of Section 1-105, contained in $1 \mathrm{NEW}$ YoRk LAw Revision CoMmission, REPORT fOR 1955, at 175 (1955).

62. For example, West Germany and Italy.

63. For Austria and Germany see text at notes 55 and 56 supra. The Observations filed by the Government of the United States took note of the matter as follows:

The transaction in question need have no contact with a state which has adopted the Uniform Law. This last point reflects the deliberate choice of the draftsmen. 
of accepted conflicts principles. It is said in explanation that the delegations were composed of specialists on sales law with little experience in conflicts. More important, probably, is the fact that the opposition was divided on the solution of the conflicts question. The controversy over the merits of the rules of the Conflicts Convention of 1951 illustrates the difficulty in agreeing on such rules. Even the motion to write into the Uniform Law the limitation that both parties to the contract must be in a ratifying state was lost on a tie vote.

After this decision the only remedy which remained was inclusion in the covering convention of reservations with respect to the territorial application of the Uniform Law. But the reservations - that both parties must have their place of business (or their residence) in contracting states, or that the Uniform Law must be applicable under the conflicts rules of the Hague Conflicts Convention of 1951 - do not solve the problem. The convention may, of course, be ratified without any reservation; the fact that insertion of a territorial limitation into the Uniform Law was opposed by half of the delegations suggests a disposition on the part of at least some states so to ratify.

Whether five states will ratify the Sales Convention with or without reservation before the "deadline" of May 1, 1968, is a matter of conjecture. The violation of the rules of conflict of laws should suffice to cause governments and parliaments to pause and study the situation. Moreover, major and minor deficiencies in the Uniform Law itself will certainly be discovered after the text becomes more generally available. Nevertheless the pressures exercised at The Hague in April, 1964, will be continued and by the same group of persons, principally members of the drafting committee. Five ratifications are relatively easy to obtain from a group of twenty-eight states with heterogeneous interests, including such important trading centers as San Marino and Vatican City. Discussions concerning ratification among the Common Market countries have already been scheduled.

Professor Tunc, of the University of Paris, a leading promoter of the Uniform Act, has advanced the following illuminating arguments in favor of immediate ratification: ${ }^{65}$ It is the duty of the nations of Western Europe which were well represented on the drafting committee to set an example by prompt ratification, for application of the Uniform Law in practice is the only effective way of testing its merits. Furthermore, Professor Tunc argues, unless the civil law countries have adopted the Uniform Law prepared at The Hague, in any future efforts at unification they will be as "mere dust" in the face of the common law countries armed with their Uniform Commercial Code and their Sales of Goods Act. Professor Tunc does not wish his remarks to be taken as an assault on the "Anglo-Saxons," but, he argues, should the

However, further consideration should be given to the possibility that unintended scope results in some circumstances.

64. See Honnold, Preface to the Text of the Conventions, to be published in 13 Ass. J. Cosp. I., No. 3 (1964).

65 . Tunc, supra note 46 , at 554 . The arguments are contained in a report on the conference. 
Uniform Law not be adopted now, the merits of the commercial practices of Europe as a whole, its conceptions of law and legal institutions, and even its style of drafting laws might be lost in the drafting of any future Uniform Law.

Furthermore, this statement from a leading French jurist who has to his credit, among other things, an outstanding work on the constitutional law of the United States, ${ }^{66}$ is incorrect in conceiving of the project as initiated solely on the Continent. From its inception, England was a full partner in the project which was originally an endeavor to unify the law of international sales of all leading trading nations. ${ }^{67}$ That was still the aim of the promoters at the 1951 Hague Conference, and such an authority as Dr. Ernst Rabel at that time saw good reason for hoping that a truly international agreement on a uniform law could be achieved. ${ }^{68}$ But the grand old men passed away, and their successors do not seem to have looked at the project in the same way. Certainly they made no effort to re-examine the draft in the light of the drafting and nation-wide acceptance of the Uniform Commercial Code in the United States, and they thus ignored Dr. Rabel's admonition in his report on the 1951 Conference: "Many a conference has miscarried or produced unsatisfactory treaties because it was not sufficiently prepared by a complete supranational survey of the field." 69

Production of a generally acceptable text requires due consideration of the American law on the subject. Even if the resolution of 1951 did not provide for American membership on the drafting committee, American participation should have been secured informally. Due consideration of American views might have required major revisions of the draft, but there is no reason to believe that this could only have been accomplished at the expense of meri* torious continental practices, as Professor Tunc asserts. Agreement on the most desirable rules for international sales contracts would call for "concessions" from all sides. American trade is as interested as any other in an agreement on uniform rules for international sales. And as far as the style of legislation is concerned, no country would bear the responsibility for a failure of the venture because of a quarrel about style.

Professor Tunc's appeal to Continentals as "civil lawyers" - as distinguished from "common lawyers" - is unfortunate. Daily experience within the Common Market shows that one cannot properly speak of a European "civil law" without qualifications. But Professor Tunc's appeal is in the French tradition, and, because the French Codes have influenced many codifications, this approach is not without effect.

Hopefully, the fate of the Uniform Law, so important to international trade, will not be decided by appeals to legal traditions. Whatever the politics

66. 1 \& 2 A. \& S. Tunc, Le Systèse Constitutionnel des Etats-Unis d'AMEnoue (1954), Yntema, Book Review, 5 Axr. J. Cosrp. L. 673 (1956); A. \& S. Tunc, Le Drort des Etats-Unis d'Amérique: Sources et Technigues (1955); El Derecho de los Estados Unidos De América (Mexico 1957) (Elola transl.).

67. See Nadelmann, supra note 28.

68. Rabel, supra note 30 , at 67 .

69. Ibid. 
of the moment, the needs of the trading community should be controlling. Since under the convention, a ratifying government is bound to the law for at least a year, ${ }^{70}$ it behooves any country considering ratification to study it carefully in advance. A year is a long time to cripple the courts, without even considering the difficulties inherent in denouncing a multilateral convention.

A much less perilous alternative to ratification is actually available to any interested country. Without ratifying the convention, its legislature could enact the Uniform Law excluding the prohibition against the forum's application of the state's normal conflicts rules or incorporating the substance of either of the two conflicts reservations. Avoiding both the problem of reciprocity and that of the inflexibility of a law adopted by ratifying a convention, the legislature would preserve its control over the law and amend it as it finds necessary. ${ }^{71}$ Further, as in the domestic example of the Uniform Commercial Code, an international watchdog committee composed of the sponsors could be appointed by the Rome Institute to insure that uniformity is preserved - if necessary by amendments mutually agreed upon. ${ }^{\text {T2 }}$ This would seem to be a much more realistic approach to unification of sales law, one which has been satisfactorily tested over a long period of time in the United States, in Canada, and also in Scandinavia.

In the United States, the immediate task is an investigation of the merits of the Uniform Law itself. According to the United States delegation to the April, 1964, Conference, the Uniform Law fails properly to balance the rights of seller and buyer in the light of the realities of trade practice, and it pays insufficient attention to the problems involved in overseas shipments. This indictment has not yet been substantiated. If found correct, positive proposals should be made for amendments to produce a more acceptable text. This is essentially a task for the academic world working in close co-operation with American foreign trade; sponsorship by one of our national organizations may also be advisable. Whatever the immediate fate of the Uniform Law, it has its place in the evolving unification of the law of international sales and demands to be carefully studied. Moreover, because of the possibility of early ratification of the convention by the minimum of five states, the task is urgent. If soon undertaken, foreign governments may await the results of the study before acting on the convention. In any case, the study will be of value to the Advisory Committee on Private International Law which the Secretary of State appointed in 1964 to assist in meeting the problems arising from

70. Sales Convention, art. XII.

71. See Nadelmann, Ways to Unify Conflicts Rules, in DE Confurctu Leguss Essays Presented to R.D. Kollewijn and J. Ofrerhaus 439 (1962), and 9 NenerIANDS TiJdSCERIFT voOR INTERNationaAx RECHt 349 (1962), with further references.

72. This has been done successfully in the case of the Uniform Commercial Code. See Malcolm, supra note 63, at 242; Nadelmann, Uniform Interprelation of "Uniform" Law: A Postscript, in Int' Institute for the Unification of Private Law, 1963 YeARBO0K, UNIFICATION of LAW; cf. Gilmore, Book Review, 73 YALE L.J. 1303, $130 S$ (1964). 
United States participation in the Hague Conference and in the Rome Institute on the Unification of Private Law. Ultimately, this committee must recom. mend how best to protect American interests in this matter.

If efforts to prevent the ratification of the Sales Convention fail, American business will not be without alternative. Any party not desiring the Uniform Law applied to its sales contracts can follow the advice freely offered by the drafting committee and protect itself from possible application of the law by inserting into all sales contracts, whatever the domicile of other parties to the contract, a standard clause that the Uniform Law of the Sales Convention shall not govern the contract. Such a clause can stand as an appropriate memorial to a short-sighted attempt to impose upon the world a uniform law not agreed upon by its principal trading nations.

American business has still another immediate problem to cope with: the fact that the Conflicts Convention became effective in 1964 for seven states. ${ }^{7 j}$ The convention's provisions thus become a part of the general law of these states and of any subsequently ratifying state. ${ }^{74}$ American business must consider its implications for international contracts. The rules of the Conflicts Convention specifically provide that parties to an international sales contract are free to choose the national law to be applied to disputes arising under the contract. $^{75}$ But the choice must be express or must appear without any doubt from the provisions of the contract. No useful general criteria can be offered on the advisability of making such an express choice, since everything depends upon the circumstances of the particular contract. Yet a party should certainly consider the possibility that a state which has ratified the Conflicts Convention may also ratify the Convention on a Uniform Law on the International Sale of Goods without reservation, or with the reservation that it will apply the Uniform Law if the rules of the Conflicts Convention require the application of that law.

If the unhappy consequences of these recent attempts to achieve uniformity have provided no other lessons, let us hope that they have at least taught us that the United States, far from being a by-stander, must take a lead in endeavors to unify the law on international sales. The world's grentest trading power must not leave the initiative to others. The legislation enacted in 1963 enabling the federal government to join the Hague Conference and the Rome Institute $^{76}$ is an expression of this newly-realized responsibility and thus

73. See text at note 27 supra.

74. Applicable Law Convention, art. 7.

75. Id., art. 2.

76. 77 Stat. 775 (1963), 22 U.S.C. $\$ 269 \mathrm{~g}$ (1964). The United States has since joincd both institutions. The new policy could be anticipated since 1956. In that year the United States accredited an observer delegation to the eighth session of the Hague Conference on Private International Law; this was done again in 1960 for the ninth session. See Nadelmann, The United States at The Hague Conference on Private International Lanu, 51 Axr. J. InT'z L. 618 (1957). Cf. Report of Special Committee on International Unification of Law 86 (1961), A.B.A. Rep. 128, 219 (1962). 
augurs well for the future. But for the belated development of this policy, the United States would probably not today have to face the manifold problems of a Uniform Law prepared without its participation.

\section{APPENDIX \\ Hague Convention of 1955 on the Law Applicable To International Sales of GoOds*}

Article 1

This Convention shall apply to international sales of goods.

It shall not apply to sales of securities, to sales of ships, or boats or aircraft which are registered, and to sales upon judicial order or by way of execution. It shall apply to sales based on documents.

For the purposes of its application contracts to deliver goods to be manufactured or produced shall be assimilated to sales if the party which assumes delivery must furnish the raw materials necessary to their manufacture or production.

A mere declaration by the parties relative to the application of a law or the jurisdiction of a judge or arbitrator is not sufficient to confer upon the sale international character in the sense of the first paragraph of this article.

\section{Article 2}

A sale is governed by the internal law of the country designated by the contracting parties.

Such designation must be the subject of an express clause or it must result without any doubt from the provisions of the contract.

Conditions relating to the consent of the parties in regard to the law declared applicable are determined by that law.

\section{ARTICLE 3}

In default of a law declared applicable by the parties under the conditions set by the preceding article a sale is governed by the internal law of the country where the vendor has his habitual residence at the time when he receives the order. If the order is received by an establishment of the vendor, a sale is governed by the internal law of the country where such establishment is located.

*Translation of the first seven articles of the Convention of June 15, 1955, prepared at the Seventh, 1951, Session of the Hague Conference on Private International Law. The original French text of the Convention may be found in CoNférence oE LA HAYE de Droit International Privé, Actes de la Septrère Sessiow, 1951382 (1952), and 40 Revue Critique de Drotr International Prive 725 (1951). For a translation of the entire Convention see 1 A3r. J. Courp. L. 275 (1952). 
However, a sale is governed by the internal law of the country where the purchaser has his habitual residence or where he has the establishment which gave the order, if the order was received in that country either by the vendor or his representative, agent, or travelling salesman.

In the case of a sale at an exchange or at a public auction, the sale is governed by the internal law of the country where the exchange is located or the auction takes place.

\section{Article 4}

In the absence of an express clause to the contrary, the internal law of the country where inspection of goods delivered pursuant to a sale is to take place shall apply as regards the form and the periods within which inspection must take place and the service of notice with respect to such inspection, as well as the measures to be taken in case of refusal of the goods.

\section{Article 5}

This Convention shall not apply:

1. to the capacity of the parties;

2. to the form of the contract;

3. to the transfer of title, it being, however, understood that the various obligations of the parties, notably those which relate to the risk, are subject to the law applicable to a sale pursuant to this Convention;

4. to the effects of the sale in regard to all persons other than the parties.

\section{ARTICLE 6}

In each of the contracting States, the application of the law determined by this Convention may be excluded on a ground of public policy.

\section{Article 7}

The contracting States have agreed to incorporate the provisions of articles 1 to 6 of this Convention in the national law of their respective countries. 